ELORE (ISSN 1456-3010), vol. 20 - 1/2013.

Julkaisija: Suomen Kansantietouden Tutkijain Seura ry.

[http://www.elore.fi/arkisto/1_13/leppalahti.pdf]

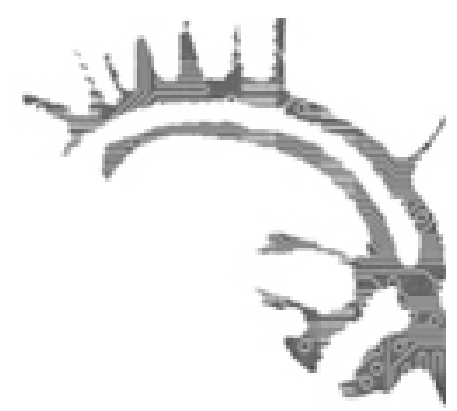

KirJa-ARViO

\title{
TAIKOJA JA USKOMUKSIA 1800-LUVULTA
}

ISSAKAINEN, TENKA 2012: Tavallista taikuutta. Tulkinta suomalaisten taikojen merkityksistä Mikko Koljosen osaamisen valossa. Turku: Turun yliopisto. <https://www. doria.fi/handle/10024/84792>. 234 sivua.

\section{Merja Leppälahti}

Tenka Issakaisen väitöskirjan keskeisenä aineistona on viitasaarelaisen, vuonna 1812 syntyneen Mikko Koljosen taika-aineistot, erityisesti ylioppilas O. H. Moision vuonna 1890 muistiin merkitsemät. Moision lisäksi Koljoselta ovat keränneet perinneaineistoja Alexander Luther vuonna 1897 sekä itseoppinut perinteenkerääjä ja kirjailija Juho Tanholin. Koljosen aineistojen lisäksi Issakainen on käyttänyt Suomalaisen Kirjallisuuden Seuran kansanuskokortistoa ja käsikirjoitussidoksia sekä Kotimaisten kielten tutkimuskeskuksen nimi- ja murrearkistoja.

Kirjoittaja ei varsinaisesti määrittele taikaa tai taikuutta, vaan paremminkin varoo sitä tekemästä. Taikuus ei ole ollut käyttäjälleen mystistä hokkuspokkusta, vaan jokapäiväiseen arkiseen elämään kuuluva asia. Toisaalta kerääjille on kerrottu myös taioista, joita kertoja ei todennäköisesti ole itse tehnyt. Joskus taikamenettelyjen kuvauksissa on esitelty myös selvästi fantastista ainesta, kuten aarteen noutaminen yksiöisellä varsalla yksiöistä jäätä pitkin tai lakin sieppaaminen pirun päästä. Tutkimuksen tarkoituksena on ollut tarkastella nimenomaan taikojen mieltä, sitä ajatusmaailmaa ja periaatteita, joihin taiat perustuvat. 
Merja Leppälahti: Taikoja ja uskomuksia 1800-luvulta

\section{SALAISET TAIAT}

Issakainen päättelee varsin uskottavasti, ettei arkistoon tallennetuista taioista voi oikeastaan varmasti päätellä, mikä taika on ollut yleinen ja millaisia taikoja on todella tehty. Arkisia ja "mitättömiä" taikoja on luultavasti kerrottu kerääjälle helposti, joten niitä on arkistossa runsaasti. Kaikkia taikoja ei kuitenkaan haluttu kertoa. Tietty taikamenettely saattoi olla siinä määrin henkilökohtaista omaisuutta, että sen tarkka kertominen toiselle tekisi taian tehottomaksi. Tiettävästi monet taikoja tuntevat jättivätkin kerääjälle kertoessaan taiasta jotakin pois, jolloin se ei menettänyt tehoaan.

Toinen selkeä syy, miksi kaikkia taikoja ei ilman muuta kerrottu, oli se, että taikoihin kuului usein jonkinlaista kiellettyä tai sopimattomana pidettyä toimintaa. Tällaista saattoi olla esimerkiksi ehtoollisleivän, vainajan osien tai hautausmaan mullan käyttäminen taikatarkoituksiin. Vahingoittava taikuus oli yleensäkin tuomittavaa.

Taiat saattoivat olla myös eräänlainen ammattisalaisuus, jota ei ollut syytä ihan kenelle tahansa levitellä. Muutenkin taikojen ilmaisemisessa oli olemassa sääntöjä, kuten se, ettei taikaa saanut kertoa itseä vanhemmalle (paitsi tietyissä erityisolosuhteissa), vaikka nuoremmalle kertominen olisi ollut luvallista. Yleensäkään taian kuvailemisen tai tekemisen tilanteessa ei ollut hyvä olla paikalla liikaa ihmisiä. Usein myös on kerrottu, ettei taiasta tehtynä tai kuvailtuna saanut pyytää maksua; toisaalta "asiakkaan" rooliin kuului maksaa toiminnasta vaikka elintarvikkeina.

Pelkästään taian ulkoinen kuvaus ei kuitenkaan kerro sen tarkoituksesta, sillä hyvin samanlaisella taialla on voitu vaikuttaa asioihin sekä suotuisasti että pilaavasti. Samaten pilaaminen ja pilauksen poistaminen on toisinaan voitu tehdä suunnilleen samanoloisella taikamenettelyllä. Tekijän tarkoitus on ollut keskeinen myös taian tuloksessa. Myös uskominen on ollut tärkeää: vaikka jokainen yksityiskohta tehdään oikein, mutta taikaan ei uskota, se ei toimi.

\section{MAAGISIA MERKITYKSIÄ}

Keskeisenä ajatuksena tutkimuksessa on, että taiat eivät ole satunnaisia "konsteja", vaan että niillä on mieli, järjestys, jonka avulla niitä voi ymmärtää ja tulkita. Tutkija, joka on sisäistänyt taikuuden symboliikan, tietää, millaisista rakennusaineista ja miten kannattaisi koota vaikka tietyntyyppinen aivan uusi taika.

Issakainen nostaa esille muutamia kiinnostavia yleisperiaatteita. Esimerkiksi kaikki läheisesti ihmisen yhteydessä ollut saattoi olla pahansuovan vieraan käsissä vaarallista. Tällaisia ovat olleet yhtä hyvin hiukset ja kynnenpalat kuin iholla pidetyt vaatteet, saunassa käytetty vihta, ulosteet tai jalanjäljetkin. Toisaalta monissa taioissa tarvitaan tuntemattoman tekijän valmistamia välineitä, kuten puukkoa tai kolmasti muutettua rakennusta. Joissakin taioissa taas tarvittiin esinettä, joka oli uusi, käyttämätön, eikä siten ollut millään tavalla sidoksissa kehenkään ihmiseen. 
Luvut kolme ja yhdeksän ovat olleet taikuudessa merkityksellisiä. Esimerkiksi syyhyvoiteessa piti olla yhdeksän ainesosaa, joista osa sai olla melkein mitä vain, kunhan lukumäärä oli oikea. Nykyään usein maagisiksi mielletyillä luvuilla seitsemän ja kolmetoista sen sijaan ei näytä olleen kovin suurta merkitystä Issakaisen tutkimassa taikuudessa. Myös taivaankappaleilla ja ilmansuunnilla on ollut merkitystä. Erityisesti kuun vaiheet ovat vaikuttaneet tiettyjen toimien menestykseen. Ilmansuunnista pohjoinen on ollut paikka, jonne asiat voidaan tarvittaessa karkottaa; pohjoinen on voinut viitata myös vainajalaan ja tuonpuoleiseen.

Mielenkiintoinen pikkuseikka, joka itseänikin hämmästytti törmätessäni siihen perinnearkiston kannakselaisuskomuksissa, on ollut suhtautuminen käen kukuntaan. Nykyäänhän käki on jonkinlainen kesän symboli, joka kukkuu elinvuosia tai aikaa ennen naimisiinmenoa, mutta varhaisemmissa mielikuvissa erityisesti kesän ensimmäinen käen kukunta on merkinnyt pahaa, se on tuonut huonoa menestystä päivän toimille.

Issakainen tarkastelee taikojen puitteissa myös väen käsitettä, samaten kuin kristinuskon osuutta ja vaikutusta taikoihin, katolisen ajan jäänteitä sekä piruun ja paholaiseen liittyviä taikauskomuksia. Trullin eli rullin toimintatapoja käsitellään myös melko laajasti. Aivan tutkimuksen lopussa nostetaan vielä esille veden ja metsän uskomusolennot, mikä on sinänsä erittäin kiinnostavaa, vaikka varsin löyhästi Koljosen taikoihin liittyvää.

\section{TAIKUUDEN PALJOUTTA}

Issakainen kirjoittaa elävästi ja jouhevasti, kuin jutustellen. Paikoin väitöskirjaa lukee melkein kuin romaania, vastaan tulee koko ajan uutta, jännittävää asiaa. Tämä on myös teoksen heikkous, koska kokonaisuus jää jollakin tavoin jäsentymättömän ja selkiytymättömän tuntuiseksi. Koljosen taikojen lisäksi viitataan paitsi saman paikkakunnan ja lähialueen muihin taikoihin, myös muualta Suomesta tallennettuihin taikoihin ja uskomuksiin. Tämä lisää teoksen mielenkiintoa yleensä taikuudesta kiinnostuneen näkökulmasta, mutta lukijan kokonaiskäsitys juuri tutkimuksen alaotsikossa mainitun Mikko Koljosen taikuudesta ja uskomusmaailmasta uhkaa jäädä hataraksi.

Koska kaikkia johtopäätöksiä ei kirjoiteta kunnolla auki, lukija ei voi tietää, mihin kaikkeen päätelmät perustuvat. Esimerkiksi käyköön sellainen yksityiskohta kuin sivulla 134 oleva maininta, että maito ja kuukautisveri ovat taikojen kannalta erityyppisiä kuin muut eritteet, koska "ne ovat syvältä ihmisen sisältä tulevia hyödyllisiä nesteitä, toisin kuin ulosteet, hiki tai sylki, joita ruumis hylkii." Ensi lukemalla tämä hämmästyttää, vaikka maidon ja kuukautisveren käytöstä on mainittu muun muassa edellisellä sivulla ulosteiden ja jalanjälkien käytön yhteydessä. Lukija voi kuitenkin muistella tutkimuksen aikaisempia mainintoja maidon ja kuukautisveren käytöstä, jolloin hän epäilemättä tekee päätelmän, että ihmisen maito ja kuukautisveri näyttävät taikuudessa tosiaankin olevan jollakin tavoin eriluonteisia esimerkiksi ulosteeseen verrattuna.

Väitöskirjojen verkkojulkaisemisen etuna on painatuskustannusten poisjäämisen lisäksi tietenkin lukijan kannalta helppo saavutettavuus ja kirjoittajan näkökulmasta painettua kirjaa laajempi levikki. Tästä huolimatta ajattelen, että Issakaisen väitöskirjan runsaasta 
Merja Leppälahti: Taikoja ja uskomuksia 1800-luvulta

sisällöstä olisi varmasti koottavissa myös mielenkiintoinen populaarijulkaisu, jolle luulisi löytyvän lukijoita. Aiheena taikuus epäilemättä kiinnostaa myös ei-akateemista yleisöä.

Filosofian lisensiaatti Merja Leppälahti on turkulainen folkloristi, tietokirjailija ja kriitikko. 